\title{
Origin and spatial-temporal distribution of faecal bacteria in a bay of Lake Geneva, Switzerland
}

\author{
John Poté • Nico Goldscheider • Laurence Haller • \\ Jakob Zopfi • Fereidoun Khajehnouri · Walter Wildi
}

Received: 24 October 2007 / Accepted: 22 May 2008 / Published online: 19 June 2008

(C) Springer Science + Business Media B.V. 2008

\begin{abstract}
The origin and distribution of microbial contamination in Lake Geneva's most polluted bay were assessed using faecal indicator bacteria (FIB). The lake is used as drinking water, for recreation and fishing. During 1 year, water samples were taken at 23 points in the bay and three contamination sources: a wastewater treatment plant (WWTP), a river and a storm water outlet. Analyses included Escherichia coli, enterococci (ENT), total coliforms (TC), and heterotrophic plate counts (HPC). E. coli input flux rates from the WWTP can reach $2.5 \times 10^{10} \mathrm{CFU} / \mathrm{s}$; those from the river are one to three orders of magnitude lower. Different pathogenic Salmonella serotypes were identified in water from these
\end{abstract}

J. Poté · L. Haller · W. Wildi

Forel Institute, University of Geneva,

10 Route de Suisse, P.O. Box 416,

1290 Versoix, Switzerland

N. Goldscheider $(\bowtie)$

Centre of Hydrogeology, University of Neuchâtel, Rue Emile-Argand 11, 2009 Neuchâtel, Switzerland e-mail: nico.goldscheider@unine.ch

J. Zopfi

Laboratory of Microbiology, University of Neuchâtel,

Rue Emile-Argand 11, 2009 Neuchâtel, Switzerland

F. Khajehnouri

Laboratory "Eauservice", Rue de Genève 36,

P.O. Box 741, 1002 Lausanne, Switzerland sources. FIB levels in the bay are highly variable. Results demonstrate that (1) the WWTP outlet at $30 \mathrm{~m}$ depth impacts near-surface water quality during holomixis in winter; (2) when the lake is stratified, the effluent water is generally trapped below the thermocline; (3) during major floods, upwelling across the thermocline may occur; (4) the river permanently contributes to contamination, mainly near the river mouth and during floods, when the storm water outlet contributes additionally; (5) the lowest FIB levels in the nearsurface water occur during low-flow periods in the bathing season.

Keywords Water pollution - Recreational water • Drinking water $\cdot$ Faecal indicator bacteria .

Microbial pathogens $\cdot$ Salmonella .

Wastewater treatment plant .

Human health risk • Lake Geneva

\section{Introduction}

Diarrhoeal diseases, mainly due to the consumption of microbiologically contaminated drinking water, cause about one billion illnesses and 2.2 million deaths per year (Montgomery and Elimelech 2007). Although most infections occur in developing countries, waterborne diseases are a worldwide problem. Bathing in polluted water (Bonadonna et al. 2002a) or the consumption 
of contaminated shellfish (Campos and Cachola 2007) can also cause disease.

Faecal indicator bacteria (FIB) are commonly used to assess the hygienic quality of drinking and recreational waters: Their presence indicates the possible presence of pathogens of faecal origin, such as Salmonella, while their absence suggests that pathogens are absent (OECD, WHO 2003). Commonly used FIB include total coliforms (TC), faecal coliforms (FC), Escherichia coli and enterococci (ENT). The two latter have the highest sanitary significance, while TC and even 'faecal' coliforms, can partly originate from non-faecal sources and thus overestimate pollution (Cabral and Marques 2006; Doyle and Erickson 2006). Heterotrophic plate count (HPC) is often used as an additional, general water quality indicator. Most national legislations and international guidelines for drinking water quality demand that E. coli must be absent in a $100 \mathrm{ml}$ sample (e.g. WHO 2004). Limits for bathing water are higher; according to the European Directive 2006/7/CE, recreational waters are to be classified as 'poor' if E. coli levels exceed $900 \mathrm{CFU} / 100 \mathrm{ml}$ and/or ENT exceed $330 \mathrm{CFU} / 100 \mathrm{ml}$.

Water quality monitoring and water treatment reduce the risk of waterborne diseases, but do not provide absolute safety. Specific pathogens, such as Cryptosporidium oocysts, may occur when FIB are absent and may resist water treatment (Hoxie et al. 1997; Bonadonna et al. 2002b). Therefore, any release of insufficiently treated wastewaters into drinking and recreational water resources is generally problematic and should be avoided or limited as much as possible. Existing microbial contamination requires careful monitoring in order to further minimize the risk.

Lake Geneva (lac Léman) has a surface area of $582 \mathrm{~km}^{2}$, a maximum depth of $309 \mathrm{~m}$ and supplies approximately 700,000 people with water (Wildi et al. 2004). Lausanne, with 127,000 inhabitants the biggest city in the region, receives $58 \%$ of its freshwater from the lake. The city and region also generate large volumes of wastewater, which are mainly released into the nearby Bay of Vidy. Previous studies focused on heavy metals and other compounds in the sediments and revealed that the bay is highly contaminated (Pardos et al. 2004; Loizeau et al. 2004; Poté et al. 2008). Water analy- ses showed that the bacteriological water quality is often poor. Therefore, the health risk at this recreational site has received attention from the municipality of Lausanne, which recommended to monitor the bacterial contamination in the bay during 1 year.

The main objectives of the study were to quantify the input flux rates of faecal bacteria from the main contamination sources and to assess their spatial and temporal distribution in the bay, in order to estimate the human health risk related to recreational activities and drinking water use. Furthermore, we aimed to characterize the influence of different hydrometeorological and limnological conditions on the bacteriological contamination, including storm events, thermal state of the lake, and other seasonal influences. Sampling and monitoring started in March 2005 and ended in February 2006. The study consisted of FIB analyses (E. coli, ENT, TC), HPC, the detection of pathogenic Salmonella serotypes, and physicochemical measurements.

Parallel to this study, we carried out two multitracing experiments with each three types of bacteriophages (short: phages) in order to simulate pathogen transport in the bay. The phages were injected at the three sites where contaminated waters enter the lake. The experiment was carried out twice, first when the lake was stratified and a second time during holomixis (Goldscheider et al. 2007). The results of these experiments help to better understand the spatial-temporal distribution of faecal bacteria in the bay and will thus be discussed along with the FIB results.

\section{Materials and methods}

Study site

The Bay of Vidy is located near the centre of Lausanne, on the northern shore of Lake Geneva (Fig. 1). There are two major contamination sources: the wastewater treatment plant (WWTP) and the Chamberonne River. The WWTP treats $\sim 1-3 \mathrm{~m}^{3} / \mathrm{s}$ of urban wastewater, which is released into the bay via an underwater pipe at $30 \mathrm{~m}$ depth, $700 \mathrm{~m}$ away from the shore. The river receives inflows of untreated wastewater. The urban storm 
Fig. 1 Map of the study area and positions of the three known point sources of water contamination (WWTP, Chamberonne, Flon) and the sampling sites (Swiss coordinates, $1 \mathrm{~km}$ grid). The drinking water pumping station is located $3.8 \mathrm{~km}$ west of the WWTP outlet, which is located directly below V14

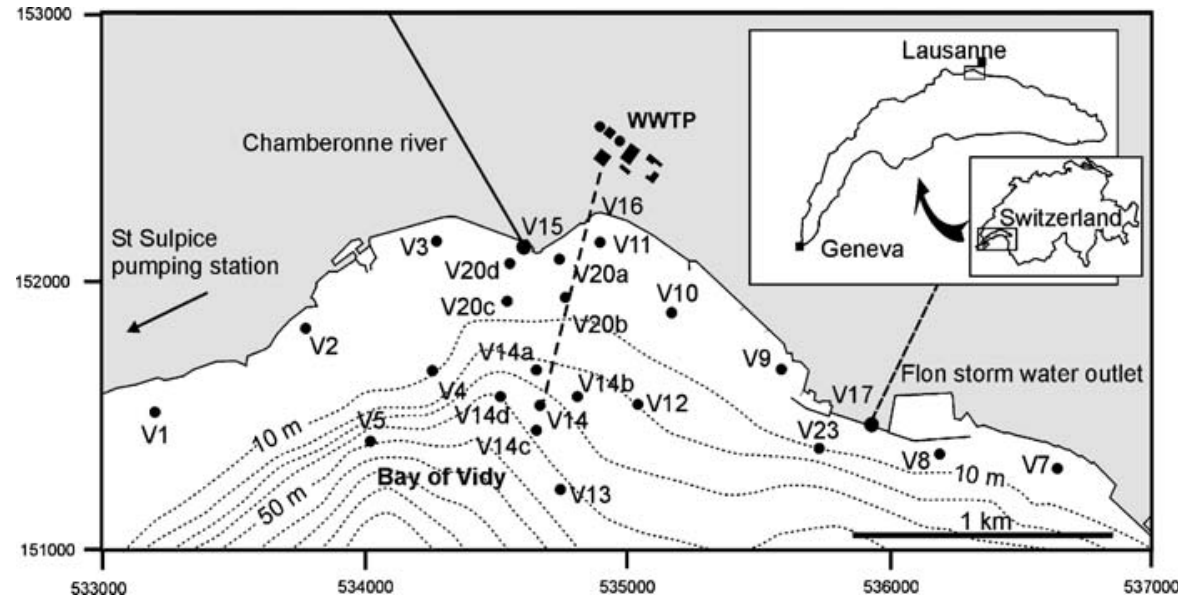

water drainage system (Flon) represents a third, transient contamination source. It collects surface and wastewater, which is usually treated at the WWTP but released into the lake during storm events, via a conduit at $10 \mathrm{~m}$ depth. The drinkingwater pumping station of St. Sulpice is located $3.8 \mathrm{~km}$ west of the WWTP outlet pipe. The water is pumped from $45 \mathrm{~m}$ depth at an average rate of $385 \mathrm{l} / \mathrm{s}$.

Water sampling and physicochemical measurements

Figure 1 shows the location of the sampling sites (V1-V23), which are distributed within the entire bay but particularly focus on zones where contaminated waters enter the lake. Within the bay, water samples were taken at $2 \mathrm{~m}$ depth using a Niskintype water sampler (40 L). V13 and V14a-d were sampled at several depths $(2-35 \mathrm{~m})$ in order to assess the vertical distribution of FIB near the WWTP outlet pipe. At the contamination sources (V15, V16, V17) and near the shore, where the water is less than $2 \mathrm{~m}$ deep (V20a, V20d), samples were collected manually. The samples were filled into sterile plastic bottles of $250 \mathrm{ml}$ for FIB analyses and of $2 \mathrm{~L}$ for Salmonella determination, placed in a cooling-box at $4^{\circ} \mathrm{C}$ and analysed within $24 \mathrm{~h}$.

Depth profiles of temperature $(T)$, electrical conductivity (EC), pH, turbidity and dissolved oxygen were recorded at V14a-d, using a YSI 600 XL multiprobe. At the outflows of the three con- tamination sources, and at V17, V20a and V20d, EC and $T$ were measured with a conductimeter (WTW, LF 325). The flow rates of the three contamination sources were measured continuously, using calibrated weirs.

\section{Microbiological analyses}

The bacteriological analyses were done in the laboratory "Eauservice" according to international standard methods for water quality determination (APHA et al. 2005). For TC, E. coli and ENT, $100 \mathrm{ml}$ of water were passed through $0.45 \mu \mathrm{m}$ membrane filters (47 $\mathrm{mm}$ diameter, Millipore), which were subsequently placed onto different culture media (Biolife): TC: Endo Agar, incubated at $35^{\circ} \mathrm{C}$ for $24 \mathrm{~h}$; E. coli: Tryptic Soy Agar, incubated at $20^{\circ} \mathrm{C}$ for $24 \mathrm{~h}$ and transferred to ECD Agar Mug for $24 \mathrm{~h}$ at $44^{\circ} \mathrm{C}$; ENT: Slanetz Bartley Agar, incubated at $37^{\circ} \mathrm{C}$ for $48 \mathrm{~h}$ and transferred to Bile Aesculin Agar medium at $37^{\circ} \mathrm{C}$ for $4 \mathrm{~h}$. Heterotrophic plate counts (HPC) were determined on Plate Count Agar (PCA) after $72 \mathrm{~h}$ incubation at $30^{\circ} \mathrm{C}$.

The results are mostly single determinations and are expressed as colony forming units (CFU) per $100 \mathrm{ml}$. The reproducibility of the analytical procedure was tested by means of triplicates of selected water samples, which revealed a mean standard derivation of $17 \%$.

For Salmonella spp. detection, 11 of water was passed trough a 0.45 membrane filter. The filter was placed into $100 \mathrm{ml}$ Rappaport Vassiliadis 
broth (Biolife 401980) for $18-24 \mathrm{~h}$ at $44^{\circ} \mathrm{C}$ in order to enrich for Salmonella spp. A sample of the enrichment was streaked out on selective and differential Hektoen Enteric Agar (Biolife 401541), and incubated for $24 \mathrm{~h}$ at $37^{\circ} \mathrm{C}$. A rapid test for Salmonella spp. (Oxoid Biochemical Identification System) was used to check putative Salmonella spp. colonies. Positive isolates were transferred to Tryptic Soy Agar (ex. Biolife 402150) and sent for serotyping to the Swiss Centre for Salmonellae diagnostics in Lucerne.

\section{Results and discussion}

Physicochemical characterization of the lake

The physicochemical depth profiles, particularly temperature, show that the water column was vertically mixed from the beginning of the measurement period in March 2005 to May 2005 and from December 2005 until the end of the measurement period in February 2006, while it was stratified from June to November 2006. A typical profile for stratified lake conditions is presented further below, together with the FIB results.

The average EC of the surface water is $290 \mu \mathrm{S} / \mathrm{cm}$ when the lake is stratified and $240 \mu \mathrm{S} / \mathrm{cm}$ when it is mixed. Higher values were observed in the WWTP effluent (average $=863 \mu \mathrm{S} / \mathrm{cm}$ ) and the Chamberonne River $(415 \mu \mathrm{S} / \mathrm{cm})$. The $\mathrm{pH}$ of the lake water is within a narrow range of 7.5 to 7.8. The lake surface water temperature varied between $5.8^{\circ} \mathrm{C}$ (February) and $25^{\circ} \mathrm{C}$ (July). The temperatures of the WWTP effluent $\left(10.3-27.4^{\circ} \mathrm{C}\right)$ and Chamberonne River $\left(4.2-23.0^{\circ} \mathrm{C}\right)$ also display clear seasonal variability.

\section{Bacterial input from the contamination sources}

The concentrations of E. coli, ENT, TC and HPC in the WWTP effluent were substantially higher than those found in the Chamberonne River. For example, $E$. coli varied between $4.0 \times 10^{4}$ and $1.2 \times 10^{6} \mathrm{CFU} / 100 \mathrm{ml}$ in the WWTP effluent, and between $1.3 \times 10^{3}$ and $5.5 \times 10^{4} \mathrm{CFU} / 100 \mathrm{ml}$ in the river. Enterococci levels were also higher in the effluent water $\left(3.3 \times 10^{3}\right.$ to $6.3 \times 10^{5} \mathrm{CFU} / 100$ $\mathrm{ml})$ than in the river $\left(3.0 \times 10^{2}\right.$ to $1.4 \times 10^{4}$ CFU/100 ml). The FIB levels found in the storm water drainage system (Flon) during floods were similar to those in the WWTP effluent water (data not shown). The measured discharge of the WWTP outlet varied between 1.0 and $5.5 \mathrm{~m}^{3} / \mathrm{s}$. As the WWTP can only treat up to $3 \mathrm{~m}^{3} / \mathrm{s}$, the excess is released into the bay without treatment during storm events. The measured flow rates of the Chamberonne River varied between 0.4 and $5.2 \mathrm{~m}^{3} / \mathrm{s}$.

For the characterisation of contamination sources, mass fluxes are more relevant than concentrations. The FIB flux rates (CFU/s) from the WWTP and Chamberonne River were calculated by multiplying the measured flow rates $(1 / \mathrm{s})$ and bacteria concentrations (CFU/l) (Fig. 2). The input flux rates from the WWTP are generally one to three orders of magnitude higher than those from the river but show a similar temporal evolution. A major storm event on the 4 July 2005 corresponds to the highest observed input flux rates of E. coli $\left(2.5 \times 10^{10} \mathrm{CFU} / \mathrm{s}\right)$ and $\mathrm{ENT}$ $\left(1.3 \times 10^{10} \mathrm{CFU} / \mathrm{s}\right)$ from the WWTP, as well as the second highest E. coli $\left(8.0 \times 10^{7} \mathrm{CFU} / \mathrm{s}\right)$ and highest ENT $\left(2.1 \times 10^{8} \mathrm{CFU} / \mathrm{s}\right)$ flux rates from the river.

The observed average flux rates for E. coli from the WWTP $\left(1.2 \times 10^{10} \mathrm{CFU} / \mathrm{s}\right)$ and the legal limit for drinking water $(<1 \mathrm{CFU} / 100 \mathrm{ml})$ mean that the effluent discharge into the lake has the potential to spoil $1.2 \times 10^{9} 1$ of drinking water per second, i.e. three million times the pumping rate of the pumping station of St. Sulpice, $3.8 \mathrm{~km}$ further to the west. Although various processes contribute to the attenuation of microbial contamination (see below), this simple calculation illustrates the potential health risk associated to the discharge of effluent water.

Correlation analyses of the four bacteriological parameters revealed strong positive correlation between ENT and E. coli in the WWTP effluent (linear correlation coefficient $r=0.95$ ), confirming the high sanitary significance of these two parameters (Table 1). Total coliforms also correlate well with these two parameters, while HPC show a weak negative correlation with the other 
Fig. 2 Input flux rates of E. coli and enterococci (ENT) from the WWTP and Chamberonne River during five sampling campaigns. Dashed auxiliary lines do not suggest linear interpolation

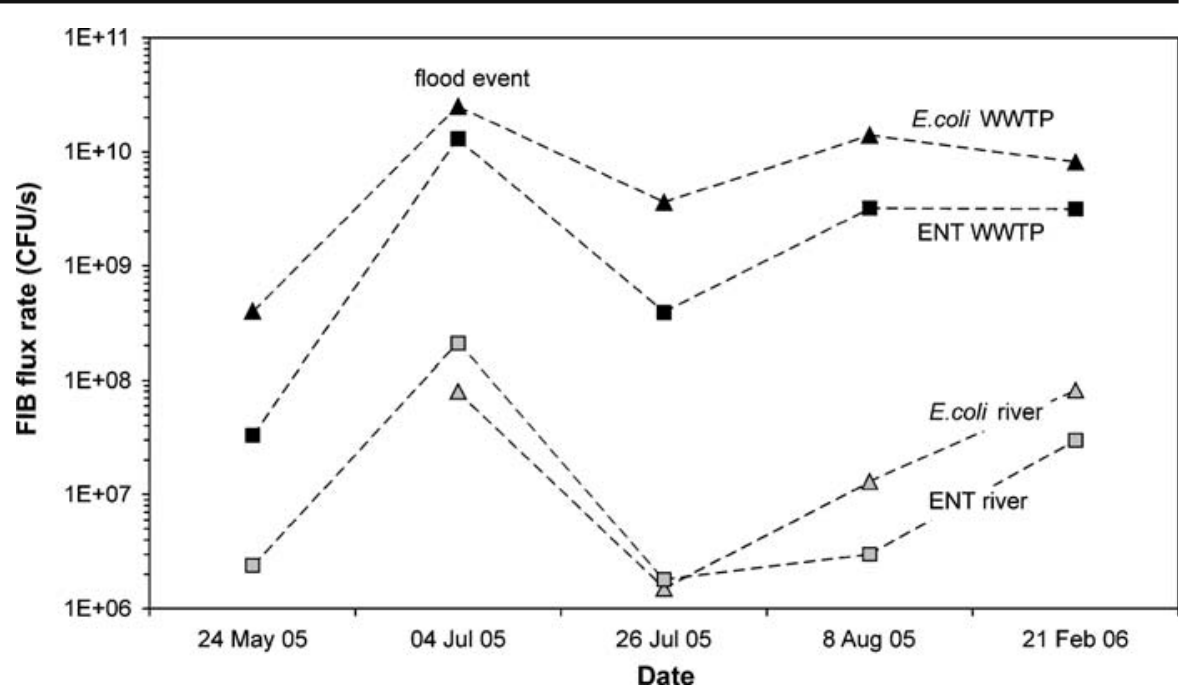

parameters $(-0.4$ to -0.1$)$, confirming the low sanitary significance of this parameter. The river water displays a different pattern, with positive correlations between HPC and all other parameters, particularly TC (0.99). Cabral and Marques (2006) also found high correlation between TC, ENT, FC and faecal streptococci in river water.

Table 1 Linear correlation coefficients $(r)$ of bacteriological parameters for WWTP effluent; Chamberonne River; lake at $2 \mathrm{~m}$ depth, > $300 \mathrm{~m}$ from the contamination sources; and a vertical profile recorded at V14c when the lake was stratified

\begin{tabular}{lrrl}
\hline TC & E. coli & ENT & \\
\hline WWTP & & & \\
-0.10 & -0.21 & -0.40 & HPC \\
& 0.93 & 0.94 & TC \\
$n=5$ & & 0.95 & E. coli \\
River & & & \\
0.99 & 0.61 & 0.77 & HPC \\
& 0.59 & 0.85 & TC \\
$n=5$ & & 0.66 & E. coli \\
Near-surface lake water & & \\
0.37 & 0.75 & 0.73 & HPC \\
& 0.37 & 0.36 & TC \\
$n=88$ & & 0.80 & E. coli \\
Vertical profile & & & \\
-0.04 & -0.12 & 0.01 & HPC \\
$n=6$ & 0.95 & 0.86 & TC \\
& & 0.90 & E. coli \\
\hline
\end{tabular}

Temporal variability of FIB concentrations in the bay

In order to characterize the variability of FIB in the bay, the results from representative sampling points at $2 \mathrm{~m}$ depth were further evaluated. Only sites with complete data series and more than $300 \mathrm{~m}$ away from the contamination sources were considered. The evaluation thus includes eight sampling sites: V1-4, V7 and V9-11. Figure 3 presents the results for $E$. coli during ten individual sampling campaigns; similar results were found for ENT and TC.

E. coli concentrations during a given sampling campaign are highly variable, e.g. 301,900 CFU/100 $\mathrm{ml}$ on the 19 April, and 0-80 CFU/100 $\mathrm{ml}$ on the 4 July 2005. This finding illustrates the heterogeneous distribution of faecal contamination; therefore, sampling only one site would be insufficient for microbial water quality monitoring.

The highest E. coli levels in the bay, up to 1,900 CFU/100 ml, were observed during a flood event on the 19 April 2005, when the lake was mixed and maximum flow rates occurred in the WWTP outflow $\left(4.9 \mathrm{~m}^{3} / \mathrm{s}\right)$ and Chamberonne River $\left(5.2 \mathrm{~m}^{3} / \mathrm{s}\right.$ ) (input flux rates are not available for this date). This suggests rapid propagation of river water in the bay and rapid upwelling of effluent from the WWTP outlet pipe at $30 \mathrm{~m}$ depth, as also demonstrated by the tracer test 
Fig. 3 Box-Whisker diagrams illustrating the variability of $E$. coli at eight representative sampling sites in the bay (>300 $\mathrm{m}$ away from the contamination sources, at a depth of $2 \mathrm{~m}$ ) during ten sampling campaigns. The different lines in the diagrams represent the minimum, lower quartile, median, upper quartile and maximum values

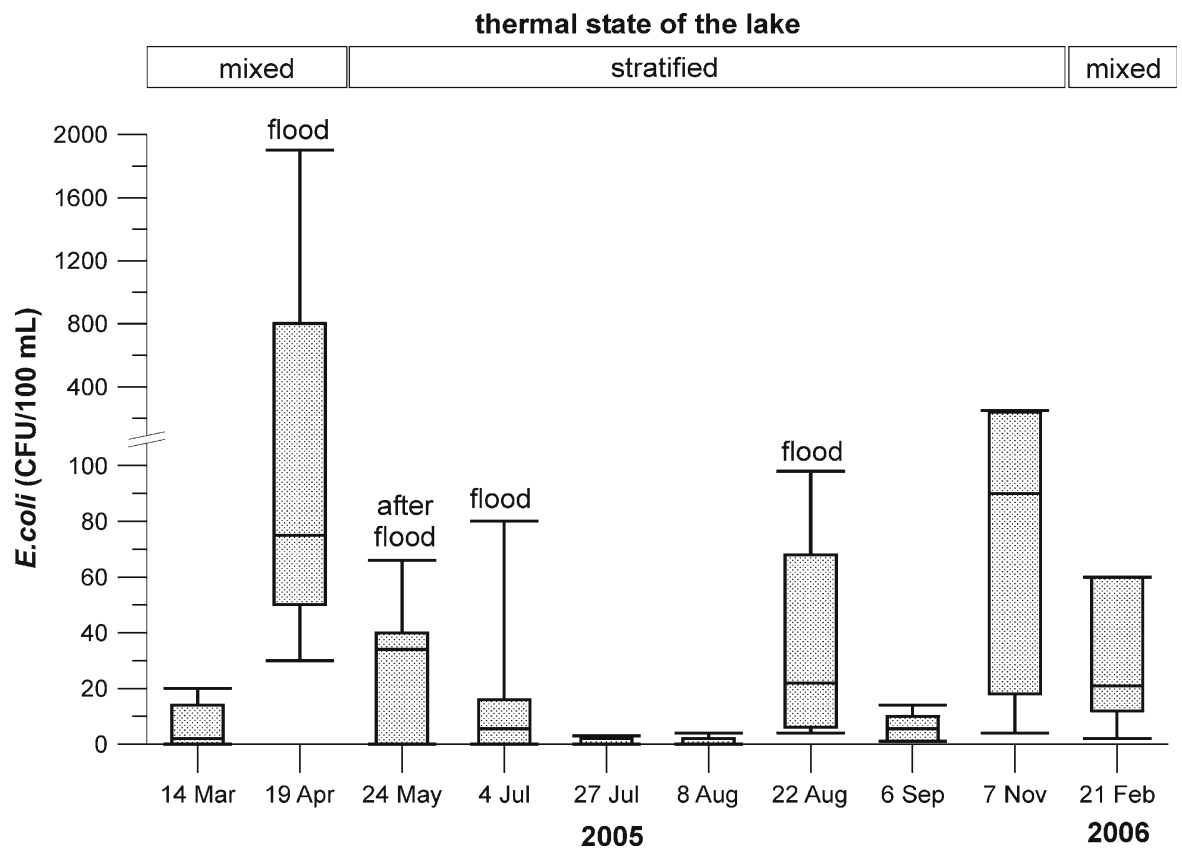

done on 21 February 2006, during holomixis: $1.14 \times 10^{14}$ phages (type H6/1) were injected near the outlet pipe; only $4 \mathrm{~h}$ later, extremely high phage concentrations were found in water samples taken in the bay at $2 \mathrm{~m}$ depth (Goldscheider et al. 2007).

Increased FIB levels also occurred during or after several other smaller storm events. Krometis et al. (2007) and Pronk et al. (2006, 2007) also found that the highest FIB levels in springs, streams and lakes often occur during floods, which can be explained by the mobilization of bacteria from soil and by the overflowing of septic tanks and WWTPs.

The lowest E. coli levels, 0-14 CFU/100 ml, were observed on the 27 July, 8 August and 6 September 2005, during low flow and stratified lake conditions, indicating that the WWTP effluent was trapped below the thermocline and the relatively low FIB input from the river was highly diluted in the lake. Similar conditions (stratified lake, low flow rates) but substantially higher FIB levels $(E$. coli $=4-250 \mathrm{CFU} / 100 \mathrm{ml})$ occurred on the 7 November 2005. The tracer test done on this very day demonstrated the effectiveness of the thermocline: $6.97 \times 10^{13} \mathrm{H} 6 / 1$ phages were injected near the WWTP outlet pipe, but not a single phage was detected in any of the 54 water samples taken at $2 \mathrm{~m}$ depth in the bay during a time period of $48 \mathrm{~h}$, confirming that the thermocline prevented vertical transport from the hypolimnion to the epilimnion (Goldscheider et al. 2007). Therefore, the different FIB levels probably reflect the seasonal dependence of FIB survival times in surface lake water. In summer, higher water temperatures, higher biological activity and higher rates of predation (grazing) by bacterivorous organisms, such as protozoans and metazooplankton, can cause a rapid decline of faecal bacteria (Brettar and Höfle 1992; Vaque et al. 1994). Brettar and Höfle (1992) also investigated the role of suspended sediment particles for the survival of E. coli and found that, on one hand, particles provide niches for bacterial survival; on the other hand, the sedimentation of these particles contributes to the removal of $E$. coli from the water column. More intense UV summery radiation further reduces the FIB levels. Hughes (2003) assessed the influence of various seasonal environmental parameters on the survival of faecal coliforms around an Antarctic research station and found that solar radiation is the dominant factor. The penetration depth of UV radiation into lake water strongly depends on the concentration of dissolved organic carbon and turbidity, and often ranges between some decimetres and several meters (Laurion et al. 2000). 
The data were also used for a correlation analysis (Table 1). As for the WWTP effluent, the highest correlation was found between $E$. coli and ENT $(r=0.80)$. On the other hand, the good correlations between HPC and the other parameters resemble the river water. This finding reflects the combined impact of the two point sources of water contamination on the near-surface lake water quality. Davis et al. (2005) carried out similar statistical analyses in lake water and also found the highest positive correlation between E. coli and ENT.

Vertical distribution of FIB in the lake water column

Vertical profiles of temperature, EC, turbidity, FIB and HPC were recorded on the 8 August 2005 during stratified lake and low flow conditions at V14c, $150 \mathrm{~m}$ south of the WWTP outlet pipe (Fig. 4). The profile displays a thermocline with an inflexion point at $20 \mathrm{~m}$ depth. Turbidity and EC generally decrease with depth but show local maximums at $20 \mathrm{~m}$, together with HPC, indicating accumulation of suspended and dissolved matter and increased microbiological activity along the thermocline. Turbidity probably originates mainly from the nearby Chamberonne River and from sinking biomass and other particles from the surface lake water.

The FIB profiles show low values for all parameters at 2 and $10 \mathrm{~m}$ water depth, underscoring the combined influence of higher water temperatures, biological activity and, in the upper few metres, UV radiation on bacteria degradation (as discussed above). Low FIB levels were also measured along the thermocline, while maximum values occurred in the hypolimnion at $25 \mathrm{~m}$ depth. These findings suggest that WWTP effluent is trapped below the thermocline, thus preventing water contamination near the surface of the lake. As described above, this interpretation was also confirmed by tracer tests (Goldscheider et al. 2007). The inverse depth distribution of FIB and HPC also demonstrates the low sanitary significance of HPC (Allen et al. 2004).
Fig. 4 Physicochemical and bacteriological profiles during stratified like conditions (8 Aug 2005, V14c): ENT, E. coli and TC show a maximum below the thermocline, which can be attributed to the WWTP outlet pipe at $30 \mathrm{~m}$, while the HPC maximum coincides with a local turbidity and EC maximum at the thermocline at $20 \mathrm{~m}$ depth. The mean relative standard deviation of the FIB data is $17 \%$

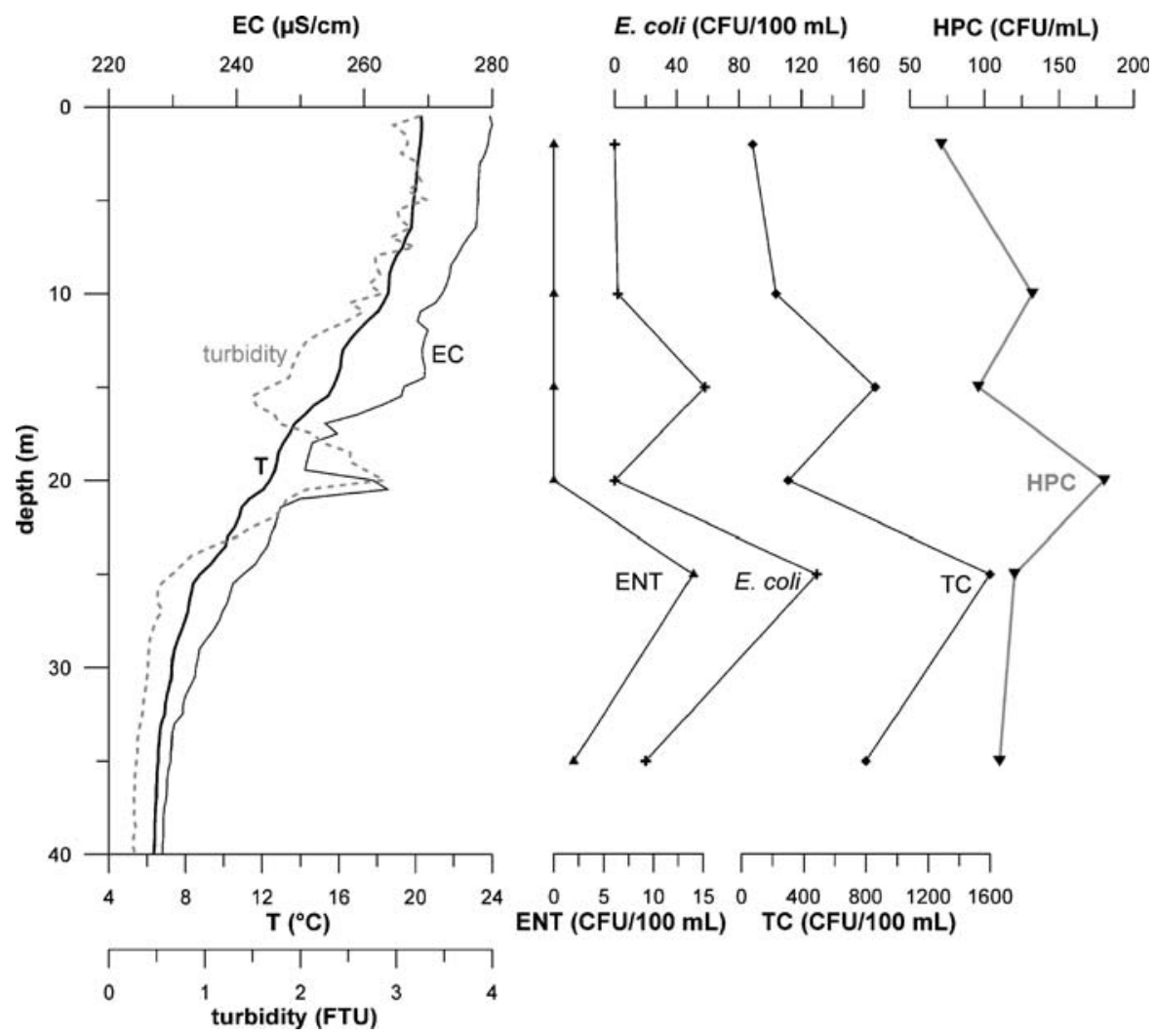


The correlation analysis of the four FIB parameters from this vertical profile (Table 1) revealed a similar pattern as for the WWTP effluent, i.e. high positive correlation between $E$. coli, ENT and TC (0.86-0.95), but only weak negative or positive correlation between HPC and the three other parameters. The vertical distribution of FIB in the stratified water column thus mainly reflects the different degrees of contamination from the WWTP outlet pipe.

Horizontal distribution of FIB near the river mouth and in the bay

Figure 5 shows the levels of E. coli and ENT at $2 \mathrm{~m}$ depth during selected sampling campaigns during distinct hydrological and limnological situations: stratified lake and flood (4 July 2005); stratified lake and low flow conditions (8 August 2005); mixed water column and flood (19 April 2005); and mixed water column and low flow conditions (21 February 2006).

The highest FIB levels often occur near the mouth of the Chamberonne River, mainly during floods, but also, to a lesser degree, during low flow conditions. The observed maximum concentrations reach 26,000 and 14,000 CFU/100 $\mathrm{ml}$ for E. coli and ENT, respectively. Lower levels were only observed in September 2005 (not shown), which can be explained by the fact that the river water is often colder than the lake surface water in autumn, and thus sinks into deeper water layers. Further away from the river mouth, the concentrations of E. coli and ENT rarely exceed the limits for bathing water but very often those for drinking water (see the "Introduction" section). The lowest levels occur during low flow conditions in summer, e.g. on 8 August 2005.

During the flood of 4 July 2005, a contamination plume seems to extend from the river mouth (V20a-d) towards the centre of the bay (V14ad), with E. coli and ENT levels up to 17,000 and 7,000 CFU/100 $\mathrm{ml}$, respectively, while they were not detectable at remoter sampling sites. However, correlation analysis of the bacteriological data from $\mathrm{V} 14 \mathrm{a}-\mathrm{d}$ revealed a similar pattern as for WWTP effluent, i.e. good correlations between TC, E. coli and ENT, with the highest correlation coefficient for E. coli and ENT ( $r=0.77)$, but neg- ative correlation coefficients for HPC and $E$. coli $(r=-0.02)$ and for HPC and ENT $(r=-0.64)$, confirming once again that HPC are not indicative of faecal contamination. Therefore, the high FIB concentrations in the centre of the bay can also be attributed to vertical upwelling of effluent water across the thermocline. This seems to contradict the results of the first tracer test described above, which demonstrated the effectiveness of the thermocline (Goldscheider et al. 2007). However, the tracer test was done in November during stable low-flow conditions, while the bacteriological data reported here suggest that the contaminant plume from the WWTP outlet pipe can penetrate the thermocline during summer floods, due to the high flow rates and high temperatures of the effluent water.

\section{Salmonella detection}

While FIB only indicate the possible presence of pathogens in a water sample, their actual occurrence is rarely checked, because such analyses are often quite expensive and time-consuming. However, this type of data is highly relevant for human health risk assessment. During this study, eight different serotypes of pathogenic Salmonella spp. were identified: Four in the WWTP effluent and five in the Chamberonne River; only the serotype 'Give' was found in both water types (Table 2). Salmonellae can survive for long periods in natural waters, sometimes more than 1 year, and the persistence and virulence of specific epidemic strains is of great concern in public health. Salmonellae can cause gastroenteritis, typhoid and paratyphoid fever (Baudart et al. 2000). However, there are relatively few studies investigating the occurrence of salmonellae in the environment, as the method of serotyping is not accessible to many laboratories. Baudart et al. (2000) assessed the diversity of Salmonella strains in different water types and found a higher diversity in river water (35 serotypes) than in wastewater (14 serotypes), and the highest diversity during floods. Although our data are less detailed, they are largely consistent with these findings. Sharma and Rajput (1996) also assessed salmonellae in fresh-water environments and found good correlation with TC, FC and faecal streptococci, 
Fig. 5 Distribution of E. coli and enterococci (ENT) in the bay during different hydrological and limnological situations: a July 2005: high flow and stratified lake, b August 2005: low flow and stratified lake, c April 2005: high flow and mixed lake, d February 2006: low flow and mixed lake
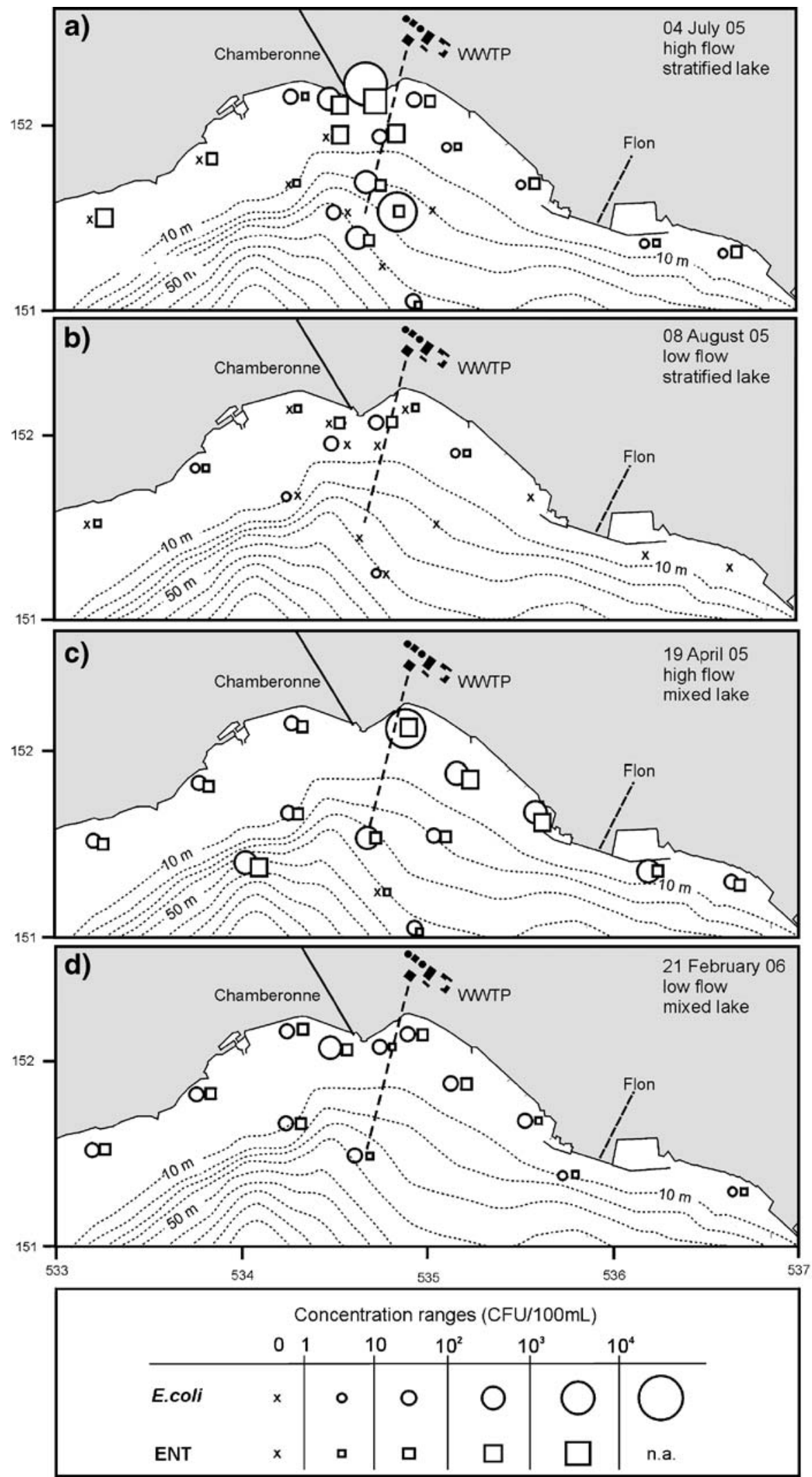
Table 2 Salmonella serotypes detected in the WWPT effluent and the Chamberonne River

ND: no Salmonella detected, -: not sampled/analysed

\begin{tabular}{llll}
\hline Sampling date & Hydrologic conditions & \multicolumn{2}{l}{ Salmonella serotypes detected } \\
\cline { 3 - 4 } & & WWPT effluent & Chamberonne River \\
\hline 14 March 2005 & Low flow & Oranienburg & ND \\
24 May 2005 & After flood & Give & Give \\
04 July 2005 & Flood & ND & Veneziana \\
27 July 2005 & Low flow & Newport & Salamae \\
08 August 2005 & Low flow & Infantis & ND \\
22 August 2005 & Flood & - & Haifa, Agona \\
\hline
\end{tabular}

underscoring both the health risk stemming from faecal contamination and the usefulness of the faecal indicator approach.

\section{Conclusions}

The input flux rates of faecal bacteria from two major contamination sources have been determined and their spatial-temporal distribution in the Bay of Vidy were assessed. FIB analyses included E. coli, enterococci (ENT) and total coliforms (TC), complemented by heterotrophic plate count (HPC). Pathogenic Salmonella serotypes were also identified.

The WWTP outlet pipe at $30 \mathrm{~m}$ depth is the largest source of faecal bacteria; the input flux rates from the Chamberonne River were typically one to three orders of magnitude lower. However, the effective contribution of these two point sources to near-surface lake water contamination depends greatly on the hydrological and limnological conditions.

When the water column is mixed, usually in winter and early spring, effluent water from the WWTP rapidly rises up to the surface, causing widespread contamination; when the lake is stratified, it is usually trapped below the thermocline. Both situations have been confirmed by tracer tests (Goldscheider et al. 2007). However, the present study suggests that upwelling of effluent water across the thermocline may occur during summer floods, when both the flow rate and temperature of the effluent are high.

Despite the lower input flux rates, the river significantly contributes to contamination, mainly during floods, but to a lesser extent also dur- ing low-flow conditions. When the river water is warmer than the surface lake water, which is often the case is spring, it spreads near the lake surface, also confirmed by high FIB levels near the river mouth. When it is colder than the lake water, which frequently occurs in autumn, it sinks down to deeper zones of the lakes, reflected in lower observed FIB concentrations near the mouth of the river.

The highest FIB concentrations in the nearsurface water of the bay consequently occur during floods and mixed lake conditions. The most favourable situation occurs when the lake is stratified and the flow rates of the river and WWTP are low, i.e. during the bathing season. Increased temperatures, biological activity and predation by bacterivorous organisms, as well as intense UV radiation, further contribute to the reduction of FIB levels near the lake surface, as also reported by Brettar and Höfle (1992), Vaque et al. (1994) and Hughes (2003). The first warm and sunny days after a major summer storm represent the most critical situation for bathers. Although the thermocline protects the epilimnion from contamination in summer, effluent water may spread in the hypolimnion and reach the drinking-water pumping station $3.8 \mathrm{~km}$ further to the west. Due to constantly low temperatures and the absence of UV radiation at greater depths, the attenuation processes descried above are expected to be substantially lower in the hypolimnion, resulting in correspondingly longer survival times of indicator bacteria and pathogens.

Acknowledgements We thank Vincent Sastre and Philippe Arpagaus (Forel Institute) for navigating R/V "La Licorne", and the City of Lausanne for funding this study. 


\section{References}

Allen, M., Edberg, S., \& Reasoner, D. (2004). Heterotrophic plate count bacteria-what is their significance in drinking water? International Journal of Food Microbiology, 92(3), 265-274. doi:10.1016/j.ijfoodmicro.2003.08.017.

APHA, AWWA, \& WEF (2005). Standard methods for the examination of water and wastewater (21st ed., 1368 pp). USA: APHA, AWWA, \& WEF.

Baudart, J., Lemarchand, K., Brisabois, A., \& Lebaron, P. (2000). Diversity of Salmonella strains isolated from the aquatic environment as determined by serotyping and amplification of the ribosomal DNA spacer regions. Applied and Environmental Microbiology, 66(4), 1544-1552. doi:10.1128/AEM.66.4.1544-1552.2000.

Bonadonna, L., Briancesco, R., Coccia, A. M., Semproni, M., \& Stewardson, D. (2002a). Occurrence of potential bacterial pathogens in coastal areas of the Adriatic Sea. Environmental Monitoring and Assessment, 77(1), 31-49. doi:10.1023/A:1015734015382.

Bonadonna, L., Briancesco, R., Ottaviani, M., \& Veschetti, E. (2002b). Occurrence of Cryptosporidium oocysts in sewage effluents and correlation with microbial, chemical and physical water variables. Environmental Monitoring and Assessment, 75(3), 241-252. doi:10.1023/A:1014852201424.

Brettar, I., \& Höfle, M. G. (1992). Influence of ecosystematic factors on survivial of Escherichia coli after largescale release into lake water mesocosms. Applied and Environmental Microbiology, 58(7), 2201-2210.

Cabral, J. P., \& Marques, C. (2006). Faecal coliform bacteria in Febros river (northwest Portugal): Temporal variation, correlation with water parameters, and species identification. Environmental Monitoring and Assessment, 118(1-3), 21-36. doi:10.1007/s10661006-0771-8.

Campos, C. J. A., \& Cachola, R. A. (2007). Faecal coliforms in bivalve harvesting areas of the Alvor lagoon (Southern Portugal): Influence of seasonal variability and urban development. Environmental Monitoring and Assessment, 133(1-3), 31-41. doi:10. 1007/s10661-006-9557-2.

Davis, K., Anderson, M. A., \& Yates, M. V. (2005). Distribution of indicator bacteria in Canyon Lake, California. Water Research, 39(7), 1277-1288. doi:10.1016/ j.watres.2005.01.011.

Doyle, M. P., \& Erickson, M. C. (2006). Closing the door on fecal coliform assay. Microbe, 1(4), 162-163.

Goldscheider, N., Haller, L., Poté, J., Wildi, W., \& Zopfi, J. (2007). Characterizing water circulation and contaminant transport in Lake Geneva using bacteriophage tracer experiments and limnological methods. Environmental Science \& Technology, 41(5), 5252-5258. doi:10.1021/es070369p.

Hoxie, N. J., Davis, J. P., Vergeront, J. M., Nashold, R. D., \& Blair, K. A. (1997). Cryptosporidiosis-associated mortality following a massive waterborne outbreak in Milwaukee, Wisconsin. American Journal of Public Health, 87(12), 2032-2035.

Hughes, K. A. (2003). Influence of seasonal environmental variables on the distribution of presumptive fecal coliforms around an Antarctic research station. Applied and Environmental Microbiology, 69(8), 4884-4891. doi:10.1128/AEM.69.8.4884-4891.2003.

Krometis, L. A. H., Characklis, G. W., Simmons, O. D., Dilts, M. J., Likirdopulos, C. A., \& Sobsey, M. D. (2007). Intra-storm variability in microbial partitioning and microbial loading rates. Water Research, 41(2), 506-516. doi:10.1016/j.watres.2006.09.029.

Laurion, I., Ventura, M., Catalan, J., Psenner, R., \& Sommaruga, R. (2000). Attenuation of ultraviolet radiation in mountain lakes: Factors controlling the among- and within-lake variability. Limnology and Oceanography, 45(6), 1274-1288.

Loizeau, J. L., Pardos, M., Monna, F., Peytremann, C., Haller, L., \& Dominik, J. (2004). The impact of a sewage treatment plant's effluent on sediment quality in a small bay in Lake Geneva (Switzerland-France). Part 2: Temporal evolution of heavy metals. Lakes and Reservoirs: Research and Management, 9(1), 5363. doi:10.1111/j.1440-1770.2004.00234.x.

Montgomery, M. A., \& Elimelech, M. (2007). Water and sanitation in developing countries: Including health in the equation. Environmental Science \& Technology, 41(1), 17-24.

OECD WHO (2003). Assessing microbial safety of drinking water, improving approaches and methods (296 pp.). London: IWA.

Pardos, M., Benninghoff, C., de Alencastro, L. P., \& Wildi, W. (2004). The impact of a sewage treatment plant's effluent on sediment quality in a small bay in Lake Geneva (Switzerland-France). Part 1: Spatial distribution of contaminants and the potential for biological impacts. Lakes and Reservoirs: Research and Management, 9(1), 41-52. doi:10.1111/j.1440-1770.2004.00233.x.

Poté, J., Haller, L., Loizeau, J. L., Garcia Bravo, A., Sastre, V., \& Wildi, W. (2008). Effects of a sewage treatment plant outlet pipe extension on the distribution of contaminants in the sediments of the Bay of Vidy, Lake Geneva, Switzerland. Bioresource Technology, 9(15), 7122-7131. doi:10.1016/j.biortech. 2007.12.075.

Pronk, M., Goldscheider, N., \& Zopfi, J. (2006). Dynamics and interaction of organic carbon, turbidity and bacteria in a karst aquifer system. Hydrogeology Journal, 14(4), 473-484. doi:10.1007/s10040-005-0454-5.

Pronk, M., Goldscheider, N., \& Zopfi, J. (2007). Particlesize distribution as indicator for fecal bacteria contamination of drinking water from karst springs. Environmental Science \& Technology, 41(24), 84008405. doi:10.1021/es071976f.

Sharma, A., \& Rajput, S. (1996). Salmonella as an index of pollution of fresh-water environments. Environmental Monitoring and Assessment, 41(1), 67-76. doi:10.1007/BF00394247. 
Vaque, D., Gasol, J. M., \& Marrase, C. (1994). Grazing rates on bacteria-the significance of methodology and ecological factors. Marine Ecology Progress Series, 109(2-3), 263-274.

WHO (2004). Guidelines for drinking-water quality, recommendations (Vol. 1, 3rd ed., 515 pp). Geneva: World Health Organisation.
Wildi, W., Dominik, J., Loizeau, J. L., Thomas, R. L., Favarger, P.-Y., Haller, L., et al. (2004). River, reservoir and lake sediment contamination by heavy metals downstream from urban areas of Switzerland. Lakes and Reservoirs: Research and Management, 9(1), 75-87. doi:10.1111/j.14401770.2004.00236.x. 